
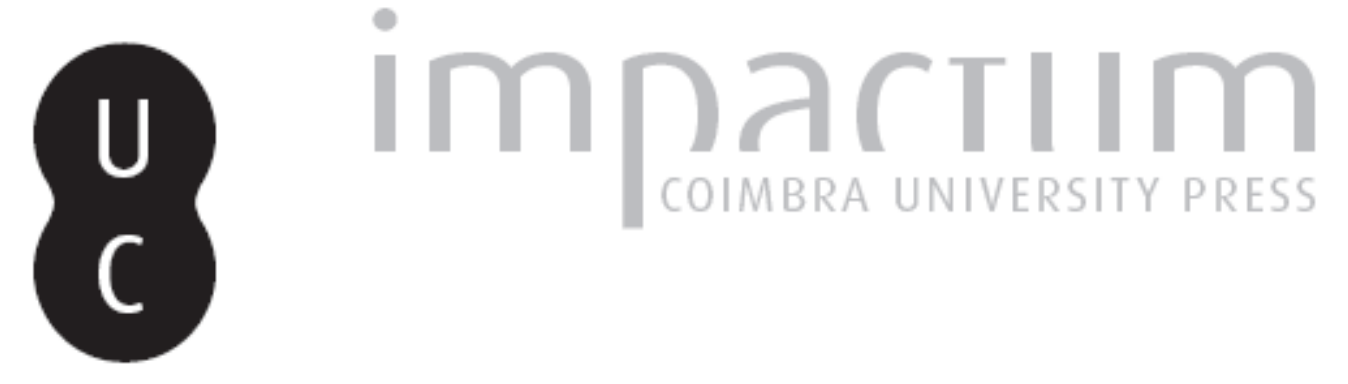

\title{
The role of culture as a vector for a common European house: the challenges of the EU action and the mobilisation of players in the field of culture to build a European casa comum
}

\author{
Autor(es): $\quad$ Bouquerel, Fanny
}

Publicado por: Imprensa da Universidade de Coimbra

URL

persistente:

URI:http://hdl.handle.net/10316.2/44839

DOI:

DOI:https://doi.org/10.14195/1647-6336_20_5

\section{Accessed : $\quad$ 26-Apr-2023 13:37:16}

A navegação consulta e descarregamento dos títulos inseridos nas Bibliotecas Digitais UC Digitalis, UC Pombalina e UC Impactum, pressupõem a aceitação plena e sem reservas dos Termos e Condições de Uso destas Bibliotecas Digitais, disponíveis em https://digitalis.uc.pt/pt-pt/termos.

Conforme exposto nos referidos Termos e Condições de Uso, o descarregamento de títulos de acesso restrito requer uma licença válida de autorização devendo o utilizador aceder ao(s) documento(s) a partir de um endereço de IP da instituição detentora da supramencionada licença.

Ao utilizador é apenas permitido o descarregamento para uso pessoal, pelo que o emprego do(s) título(s) descarregado(s) para outro fim, designadamente comercial, carece de autorização do respetivo autor ou editor da obra.

Na medida em que todas as obras da UC Digitalis se encontram protegidas pelo Código do Direito de Autor e Direitos Conexos e demais legislação aplicável, toda a cópia, parcial ou total, deste documento, nos casos em que é legalmente admitida, deverá conter ou fazer-se acompanhar por este aviso.

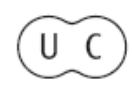


DEBATER

A EUROPA

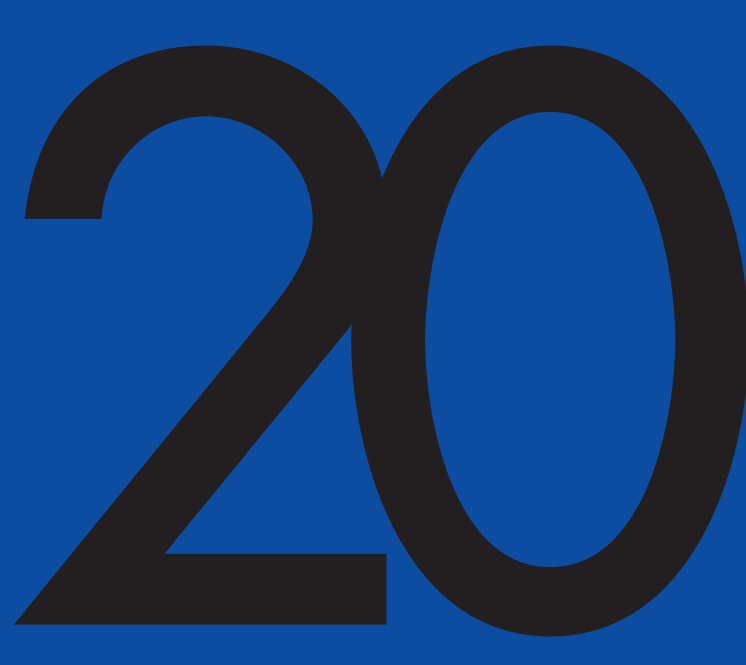

jan-jun 2019

EUROPA — UMA CASA COMUM?

EUROPE - A COMMON HOUSE? 


\title{
The role of culture as a vector for a common European house. The challenges of the EU action and the mobilisation of players in the field of culture to build a European casa comum ${ }^{1}$
}

Fanny Bouquerel

CRESPPA- LabTop,

Université Paris 8

fannybouquerel@gmail.com

\begin{abstract}
At a time when the European project seems to have reached a stalemate, culture may be a valuable tool to find new ways to go forward and to contribute to lay the foundation of a European house. This paper explores the EU action related to culture and the role cultural actors may play in fostering a cohesive European society open to its neighbours and beyond. It analyses two cases: the implementation of the EU cohesion policy in Sicily, at the extreme south of Europe and in the heart of a turbulent Mediterranean, and the role of European cultural networks supported by EU institutions and promoting transnational cultural cooperation. It analyses the articulation between the EU cultural action, and the way it may answer the needs and priorities of the cultural players, supporting the development of uma casa comum.
\end{abstract}

Keywords: cultural field, European integration, cohesion policy, Sicily Region, cultural networks.

The process of the building of Europe is not a long river that glides along, and today, as the sociologist Monica Sassatelli puts it, one may wonder if it has lost the plot $^{2}$. In other words, it seems that the recipe to build "unity in diversity", the motto of the EU project trying to find ways to unite different people in a "casa comun", is not effective any more.

1 The author would like to thank Christiane Dabdoub Nasser for her review of the text in English.

2 SASSATELLI Monica - Has Europe lost the Plot? In CHENAL, Odile, SNELDERS, Bas - Remappings. The Making of European Narratives. Amsterdam: European Cultural Foundation, 2012. ISBN 9789062820580. 
On the one hand, the home that was dreamt and implemented by the founders of Europe, with its robustness and its fragility, seems incapable to host the European people any longer, as the Brexit vote has shown in 2016 in a dramatic way. On the other hand, Europe is seriously challenged by populations fleeing from Africa and the Middle East and risking their lives to reach it. The flows of migrants who tried to enter Europe in 2015 led to one of the most serious crises of the European project, and the conclusions of the European Council in June 2018 have shown that migration is still one of the most sensitive and challenging issues of the European agenda, revealing strong disparities among Member States' positions. Culture may be a valuable tool to find new ways to contribute to overcome this stalemate. Indeed, even if culture is the expression by excellence of one's singularities and has brought about dramatic conflicts ${ }^{3}$, it is also recognised as a vector to strengthen societies' identities and cohesion. In this sense, culture could play a key role in the building of Europe, and lay the foundation of a European house - uma casa comum. But is there such a thing as a European culture and how to define it? And if culture can be mobilised to carry on the EU integration process, how the EU action could foster its development?

There is no unique definition of culture, let alone of a European culture. Following the anthropological "modern" sense of culture referring to societies that produce culture through their interaction, culture appears as a particularly volatile notion - it is precarious precisely because of its social component ${ }^{4}$. However, in an attempt to define what European culture could be, different approaches could be adopted. First, the historical perspective developed by Paul Valéry suggests that the notion of a European culture is based on a Mediterranean heritage shaped by three influent components. For him, "any race and any land which has been successively Romanized, Christianized and subjected, in terms of spirit, to the discipline of the Greeks, is absolutely European ${ }^{5 *}$. For the philosopher Denis Rougemont, who strongly believed that only culture could save Europe after the Second World War, the contribution of the German people was essential as they promoted the freedom of association, which in turn has inspired the European federalism. Another way to try and identify the specificities of Europe as an entity touches upon the analysis of its relation to the others through a dialogic perspective. For Rémi Brague, "European distinguishes itself from other cultural worlds through the specific mode of its relation to what is its own, appropriating what is perceived as foreign ${ }^{6 *}$. In other words, Europeans have a unique way to make other cultures their own. This perception leads to another

3 STEINER George - Dans le château de Barbe Bleue, notes pour une redéfinition de la culture. Paris: Gallimard, 1986. ISBN 9782070323678.

4 REMOTTI, Francesco - Cultura, dalla complessità all'impoverimento. $4^{\text {th }}$ edition. Roma-Bari: Laterza, 2011. ISBN 9788842095873.

5 VALERY, Paul - L'Européen. First published in La Revue Universelle, 1924. Reprinted In Europes de l'Antiquité au XXe siècle. Paris: Robert Laffont, 2000. ISBN 9782221085752.

6 BRAGUE, Rémi - Europe, la voie romaine. Paris: Gallimard, 1992. ISBN 2070408779, p. 120. 
vision, seeing Europe as a process that needs to be thought through and that may be subject to variations - one could be more or less European and this perception may vary over the years. As Edgar Moring puts it, one needs to Think Europe and before considering its community of intention, it needs to consider its community of destiny ${ }^{7}$. For Beck and Grande $^{8}$, there is no Europe but an institutionalised process that evolves along the way. One of its main difficulties is related to the fact that our usual framework of thought is not pertinent to think this process: beyond the national scale, one should shift to a cosmopolitan approach to question this process and contribute to it in a critical way.

Culture also alludes to heritage and works of arts from the past, as well as to the contemporary production of cultural goods. Through their work, dealing with our imaginary world, artists and cultural practitioners have the power to influence our perception of the world ${ }^{9}$. Fostering reflexive interactions, they also contribute to build communities who in turn contribute to shape Europe ${ }^{10}$. Since artists and cultural actors have been travelling for centuries, exchanging and getting influenced one by another from the beginning of art history, they have contributed to the making of Europe, a cultural Europe, in a subtle way. More broadly, culture encompasses the professional field composed of many actors described in the Art Worlds by H.S. Becker ${ }^{11}$. It has progressively been acknowledged as a significant and dynamic professional field, leading to an increased recognition of its contribution to economic development ${ }^{12}$. In other words, the assets of culture made it a valuable field to address for the EU, which designs and implements a cultural action through a series of papers, policies and programmes.

This paper will present succinctly how culture was progressively introduced in the EU legislative and political framework; it will then focus on the way it was translated into programmes and actions, questioning the way it may support the development of a cultural field in Europe. After a brief review of a number of milestones that reflect the cultural orientation of the EU, I will first tackle the cohesion policy, which is by far the EU policy that allocates more funding for culture. In that sense, the cohesion policy offers an opportunity for cultural players to develop their work while contributing to the "harmonious" development of Europe and to its integration process, which is the main objective of the

\footnotetext{
7 MORIN Edgar - Penser l'Europe. Paris: Gallimard, 1987. ISBN 2070325849, p. 20.

8 BECK Ulrich, GRANDE Edgar - Cosmopolitan Europe. Cambridge: Polity, 2007. ISBN 9780745635637.

9 PEQUIGNOT, Bruno - La question des oeuvres en sociologie des arts et de la culture. Paris: L'Harmattan, 2007. ISBN 9782296029330.

10 GIELEN, Pascal (ed.) - No Culture, no Europe. On the Foundation of Politics. Amsterdam: Antennae Valiz, 2015. ISBN 9789078088868.

11 BECKER, Howard-S - Art Worlds. University of California Press, 2008. ISBN 9780520256361.

12 KEA European Affairs - The Economy of Culture in Europe. Study prepared for the European Commission. Brussels, 2006. According to this document, the cultural and creative sector represent 2,6\% of the EU GDP in 2003. [OnLine] [20 $0^{\text {th }}$ May 2018]. Available at www: http://ec.europa.eu/assets/eac/culture/library/studies/cultural-economy_en.pdf $>$.
} 
cohesion policy. However, the implementation of this policy raises some challenging issues that were explored through a field research in Sicily, at the extreme South of Europe ${ }^{13}$. Then, I will address the resources and strategies of cultural professionals engaged in European cultural networks, analysing how European institutions have engaged with these organisations. My analysis will bring some elements related to the way the EU action contributes to the building of a cultural community through the study of the priorities it tackles, the methodologies that are used to implement its action, and the profile of the players who are committed to this process. In other words, I will explore the articulation between the EU cultural action and the way it may answer the needs and priorities of the cultural players and support a European casa comum.

\section{The milestones of the EU cultural action}

Culture was included in the European legislative corpus thirty-five years after the foundation of the European Communities in 1957. Even if initiatives addressing culture were already carried out by European institutions before 1992, it is only with the Maastricht Treaty that culture is officially taken into account as a supporting competency. In other words, the EU coordinates and supplements the action of the Member States following the principle of subsidiarity: as cultural policies deal with sensitive issues such as the building of a national identity, Member States did not wish to delegate their competences in culture to the $\mathrm{EU}^{14}$. In the Maastricht Treaty's article dedicated to culture, it is stipulated that the EU shall contribute to the improvement of the knowledge and dissemination of the culture and history of the European peoples; bring the common cultural heritage to the fore while respecting the national and regional diversity of the Members States; encourage cultural cooperation with third countries, and take culture into account in different policies and programmes. In other words, it opens the possibility for a wide range of programmes to fund cultural projects in as much as they can contribute to achieve the objectives of developmental, external, employment, etc. policies.

The publication in 2007 of the European Agenda for Culture in the era of Globalization $^{15}$ (Agenda) resulting from of a wide consultation of the cultural sector, marks a turning point in offering a vision for an EU cultural action. The Agenda refers to the growing awareness that the EU has a role to play in cultural terms, it lists various sche-

13 BOUQUEREL, Fanny - Culture et politique régionale de l'Union européenne. Acteurs et dynamiques d'un cadre d'intervention inopérant : la région Sicile, PhD thesis. Université Paris 8 Saint Denis, 2015.

14 For an analysis of the European action in the field of culture, see CALLIGARO, Oriane, VLASSIS, Antonios - La politique européenne de la culture [Online], Politique européenne, L'Harmattan, 2017/2, n.56, p.8-28. DOI 10.3917/poeu.056.0008.

15 Communication COM (2007) 242 final on a European Agenda for culture in a globalizing world. [OnLine] [20 $0^{\text {th }}$ May 2018]. Available at www: https://eur-lex.europa.eu/LexUriServ/LexUriServ.do?uri=COM:2007:0242:FIN:EN:PDF >. 
mes and programmes the European Commission (EC) has developed with success, and it underlines the necessity to provide a strategic umbrella to all these initiatives. It also sets three main objectives dealing with the promotion of cultural diversity and intercultural dialogue, the contribution of creative industries to growth and jobs, and the role of culture in the Union's international relations. Recently, a communication prepared jointly by the EC and the High Representative of the Union for Foreign Affairs and Security Policy, dealing with a strategy for culture in international relations, has raised some new interest in the soft power of culture to promote the EU on the global scene ${ }^{16}$. In addition, the 2018 European Year of Cultural Heritage has cast light on a multitude of initiatives, both from institutions and civil society organisations, which contributed to foster awareness about the social and economic role of heritage. Last but not least, the EC has published in May 2018 A New European Agenda for Culture" (New Agenda) leaning on a "unique

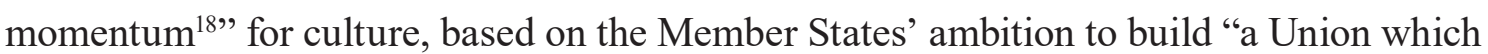
preserves [European] cultural heritage and promotes cultural diversity ${ }^{19}$ ", and on their conviction that education and culture are keys to "strengthen European identity" 20 . The New Agenda aims to harness the potential of culture to make the EU more attractive and contribute to an inclusive growth that shall provide quality jobs for its citizens ${ }^{21}$. Not surprisingly, the main three objectives in the New Agenda are in line with the orientations of the EU action developed up till now, promoting culture to strengthen cohesive societies, fostering diversity and facilitate mobility; strengthening favourable economic ecosystems for the cultural and creative sectors; and reinforcing cooperation and intercultural dialogue on the international scene. It promotes the mainstreaming of culture, and though it puts a new emphasis on education ${ }^{22}$, the economic dimension of culture appears predominant - an approach questioned in research and professional cultural arenas debating about the instrumentalisation of culture by EU institutions. The number of actions the European Commission intends to develop and the way it invites the Member States to

16 Communication JOIN (2016) 29 final -Towards an EU strategy for international cultural relations [OnLine] [20 ${ }^{\text {th }}$ May 2018]. Available at WWW: <URL: https://eur-lex.europa.eu/legal-content/ $\mathrm{EN} / \mathrm{TXT} / \mathrm{PDF} /$ ?uri=CELEX:52016JC0029\&from=EN>.

17 Communication from the Commission A New European Agenda for Culture COM (2018) 267 final [OnLine] [20 ${ }^{\text {th }}$ May 2018]. Available at www. https:/ec.europa.eu/culture/sites/culture/files/commission_communication__a_new_european_agenda_for_culture_2018.pdf >.

18 According to the words of Tamás Szücs, a European Commission member, during a workshop organised at the European University Institute on the $24^{\text {th }}$ May 2018 in Florence.

19 Declaration celebrating the $60^{\text {th }}$ anniversary of the Treaties of Rome [OnLine] [20 $0^{\text {th }}$ May 2018]. Available at www: http://europa.eu/rapid/press-release_STATEMENT-17-767_en.htm>.

20 Communication COM (2017) 673 final Strengthening European Identity through Education and Culture [OnLine] [20 ${ }^{\text {th }}$ May 2018]. Available at www: https:/ec.europa.eu/commission/sites/beta-political/ files/communication-strengthening-european-identity-education-culture_en.pdf $>$.

21 Following the Europe 2020 Strategy. Communication COM (2010) 2020 final. Europe 2020, A Strategy for a smart, sustainable and inclusive growth. [OnLine] [20th May 2018]. Available at www: https://eur-lex.europa.eu/legal-content/EN/TXT/PDF/?uri=CELEX:52010DC2020\&from=EN>

22 Introducing the notion of cultural capability. 
assume their responsibilities looks in contrast rather ambitious, even if no detail is given about the way these initiatives should be implemented. In any case, the publication of the New Agenda reflects the state of the arts of the EU cultural action nowadays: an approach to culture and the creative sector that increasingly concentrates on its economic asset; a number of actions fostering culture provided it promotes objectives that serve social, economic, environmental or security policies; and a delicate balance between the role that all the stakeholders dealing with culture should engage in to implement a European cultural agenda, be they institutions, cultural organisations or private sector.

To implement these agendas, the European Commission has developed since the 90' a series of programmes addressing culture, such as "Creative Europe", formerly named "Culture", promoting mobility, cultural diversity, and more recently competitiveness in the cultural and creative fields. It has also offered many other opportunities to fund cultural projects through programmes that are not dedicated to culture. If this has allowed to dramatically increase the resources available for culture, it has also induced a series of constraints that have influenced the effect of the EU action on the cultural professional scene.

\section{The European Cohesion Policy through the lenses of the cultural field in Sicily}

The European Cohesion Policy, also named the European Regional Policy, is a major European policy aiming at reducing economic and social disparities throughout the continent $^{23}$. Its financial envelope, which represents one third of the EU budget, is allocated through the Structural funds ${ }^{24}$. General orientations are set at the communitarian level and translate into a series of programmes at national and local levels that address the needs and specificities of each country and region. The European Cohesion Policy involves a broad partnership including governmental authorities, the private sector, as well as civil society organisations. This configuration allows this policy to offer the potential to mobilize a considerable amount of people working at the national, regional and local level. Last but not least, its common methodology for implementation aims to facilitate the adoption of a shared "language" and a common modus operandi that should contribute to the European integration.

As culture is acknowledged for its contribution to socio-economic development, it could be given a predominant role in the framework of the cohesion policy. Some regions have chosen to invest massively in culture, such as Sicily, an autonomous region that has the competence to have its own cultural policy. This large island in the Mediterranean

23 See MANZELLA, Gian Paolo - Una politica influente. Vicende, dinamiche e prospettive dell'intervento regionale europea. Bologna: Il Mulino, 2011. ISBN 9788815149282. For the historian Tony Judt, regional expenditures a few years after the Treaty of Rome were "the leading source of budgetary expansion in Brussels and by far the most influential lever at the Community's disposal" JUDT, Tony - Postwar. London: Vintage, 2010. ISBN 9780099542032.

24 Mainly the European regional development Fund (ERDF) and the European Social Fund (ESF). 
counts five million inhabitants and due to its low economic development level, it is one of the regions that benefits the most from the European Structural Funds. For the cycle 2000-2006, it decided to allocate around one billion euros to an axis that was fully dedicated to culture ${ }^{25}$. However, this opportunity didn't translate into a dynamic cultural and artistic scene, which I will explain by addressing a number of issues.

\subsection{Apprehension of the paradigm of culture between EU and Sicily}

At the end of the 1990s, culture was given some attention in the framework of the cohesion policy as it was considered a means to preserve and enhance heritage, a major local asset, which would in turn stimulate tourism and provide employment. In 1996, the European Commission recognized the value of culture for employment, considering that culture was an "underexploited Potential"26. In the orientations it published for the 20002006 cycle $^{27}$, culture associated with tourism is identified as one of the three sectors "with particular potential" that should be promoted. The private sector should contribute to a development strategy leaning on culture, and Member States are encouraged to foster cultural enterprises to better exploit their potential in terms of job creation. In the next cycle, 2007-2013, the communitarian orientations include only a brief, there is a brief reference to the way culture can contribute to the attractiveness of cities and regions through the preservation and the development of cultural heritage with potential spin offs for tourism $^{28}$. In this sense, natural and cultural heritage should be part of an integrated approach to development in large cities as well as in rural regions. For the cycle 2014-2020, even if the role of culture is recognised as a valuable economic field ${ }^{29}$, it remains very marginal in the orientation documents ${ }^{30}$.

25 Out of the 8,5 billion Euros allocated to the whole Regional Operational Programme Sicily 20002006.

26 Communication from the Commission Cohesion Policy and Culture: a contribution to employment COM (96) 512 final. [OnLine] [20th May 2018]. Available at www: http://aei.pitt.edu/6283/1/6283.pdf>.

27 Communication from the Commission concerning the Structural Funds and their coordination with the Cohesion Fund: Guidelines for the programmes in the period 2000-2006 COM (1999) 344 final. For a summary of the text, see [OnLine] [20th May 2018]. Available at www: https://eur-lex.europa.eu/ legal-content/EN/TXT/HTML/?uri=LEGISSUM:g24202\&from=FR>

28 Council Decision on Community strategic guidelines on cohesion (2006/702/EC) [OnLine] [20th May 2018]. Available at www: https:/eur-lex.europa.eu/legal-content/EN/TXT/PDF/?uri=CELEX:32 006D0702\&from $=\mathrm{EN}>$.

29 Communication from the Commission A New European Agenda for Culture COM (2018) 267 final [OnLine] [20 ${ }^{\text {th }}$ May 2018]. Available at www. https://ec.europa.eu/culture/sites/culture/files/commission_communication__a_new_european_agenda_for_culture_2018.pdf >.

30 Regulation (EU) of the Parliament and the Council laying down common provisions on the European Regional Development Fund, the European Social Fund, the Cohesion Fund, the European Agricultural Fund for Rural Development and the European Maritime and Fisheries Fund n¹303/2013 [OnLine] [20th May 2018]. Available at www: https://eur-lex.europa.eu/legal-content/EN/TXT/PDF/?uri=CEL EX:32013R1303\&from $=$ FR $>$. 
Also, the paradigm of culture shifts more radically from cultural heritage to the creative sector, including design, fashion and even advertisement, and aims at contributing to innovation, without giving culture due recognition.

In Sicily, during the 2000-2006 cycle, the development strategy was based on the exploitation of the region's exceptional cultural resources to promote cultural tourism- particularly architectural and landscape heritage. Based on the priority defined at the national level (promotion of cultural and historical assets), the Sicily Region dedicated one full axis to cultural resources, especially cultural heritage, which was managed entirely by the regional Department of Culture. Culture was also mentioned in an axis dedicated to cities, with the building of strategic urban infrastructures for contemporary arts activities. In addition, Sicily's internationalisation of cultural activities was promoted through the production and dissemination of artistic works and festivals in international circuits ${ }^{31}$. In the end, and apart from the cataloguing of tangible and intangible cultural goods or the organisation of large events, most of the resources available were used to restore a huge number of cultural sites and buildings, including archaeological sites and churches, that were under the responsibility of the Region. Although the quality of the restoration work and the engagement of the regional staff involved in this process were acknowledged, not much attention was paid to the management of these buildings, or to support the professional development of a cultural sector that could operate in a variety of disciplines beyond heritage. Consequently, the effects of this axis were rather poor in relation to the cohesion policy objectives that focused on development. For the following cycle (20072013), the programme set one axis to promote cultural identities and environmental landscapes to increase tourism attractiveness and foster development ${ }^{32}$. This common axis shared with the Environment and Tourism Regional Departments aimed at promoting an integrated management of local assets to stimulate tourism demand. However, the decrease in the resources allocated to this axis, especially to the culture component, indicates the recession of culture in the Sicily Region development strategy. In addition, the implementation of this axis proved to be particularly challenging as it involved different departments that did not work together. In other words, the mainstreaming of culture, which stems from the EU approach to culture, and the divergent interpretation of the cultural paradigm in Brussels or Sicily has weakened its role. While the EU perspective reflects a one-dimensional vision paying attention mostly to its economic impact, the Sicily Region's cultural department aimed primarily at preserving its heritage, giving priority to the historic and symbolic value of its assets. This phenomenon also reflects the challenge of addressing culture, which by nature is a vector to express plurality, as a shared vision throughout the continent.

31 Programma Operativo Regionale Sicilia 2000-2006.

32 Programma Operativo Fondo Europeo per lo Sviluppo Regionale (FESR) Sicilia 2007-2013. 


\subsection{The distortion of the partnership principle}

With the Single Act in $1986^{33}$, Jacques Delors introduces the major idea of the establishment of a partnership between the Community, the Member States and the Region to implement a cohesion policy. This document establishes that this policy is governed by a few rules and principles, among which the principle of partnership. In other words, all the stakeholders of a region should be associated to the programming, implementation and monitoring of the actions defined in the framework of the cohesion policy to guarantee its success. However, though institutions had to organise a series of consultations to mobilise all the players operating at the regional level, observers have questioned the way this partnership was implemented.

There are several reasons as to why: first, participating in consultations is conditioned by the legitimacy to represent a group in a formal way, depending on the rules for territorial representation, which excludes people who could bring valuable contributions. Already marked by a high level of fragmentation and deprived of strong representative figures, the culture field was marginalised even further by such a process. A research led in Italy about the influence of European regional policy on regional representation dynamics has also shown that in many cases, regions have followed the directive to consult economic and social organisations in a purely formal way, and never actually involved local players to design and implement their policies ${ }^{34}$. Even if the inclusion of new stakeholders as a result of partnerships had changed the group of people involved in the process, it very rarely succeeded in significantly influencing the "rules of the game" and the decision-making procedures. In addition, one needs to be well prepared to master the level of technicality required to understand the stakes, the constraints, and the margins of manoeuvre left to effectively bring a contribution to the design and implementation of the regional operational programmes. Last but not least, the partnership's role is strictly consultative and there is little the European Commission can do to make sure that the voices expressed in these circles are taken into account. It is thus no wonder if some stakeholders who had tried to engage in this process were disillusioned. The "Code of conduct on Partnerships" 35 published in 2014 by the European Commission and aiming to support and facilitate Members States to manage their Partnership Agreements

33 Communication from the Commission The Single Act: A new frontier for Europe (COM(87)100) [OnLine] [20th May 2018]. Available at www: <URL: http:/ec.europa.eu/dorie/fileDownload. do;jsessionid=0-4IywJrlsIpAyGUT5UCTRORKuwirWbx3u-5FzO0nggaebJOWnwg!-898031139?docId=1 443101\&cardId $=1443100>$

34 FARGION, Valeria, MORLINO, Leonardo, PROFETI, Stefania - Europeizzazione e rappresentanza territoriale. Il caso italiano.

35 The European Code of Conduct on Partnership in the framework of the European Structural and Investment Funds [OnLine] [20 $0^{\text {th }}$ May 2018]. Available at www: https:/eur-lex.europa.eu/legal-content/ EN/TXT/PDF/?uri=CELEX:32014R0240\&from=EN>. 
reflects both the ambition and the limited power of the European Commission to influence these processes taking place at the national and regional level.

According to several researchers, the profile of the local political classes could be considered as another reason why the partnership principle seemed askew ${ }^{36}$. The challenges related to the implementation of cohesion policy are certainly not limited to Sicily, and difficulties could be identified in different countries of the European Union. Yet, following my fieldwork, it seems that the obstacles related to the implementation of this policy are particularly acute in Sicily. The fact that the main actors of the European regional policy are the regional administrations themselves have had an impact on the way it was implemented and influenced the results that were reached in Sicily. First, as the jurist Sabino Cassese asserts in a short essay, the primacy of politics on the administration in Italy has not allowed the emergence of a high public administration, as it exists in other countries ${ }^{37}$. Partly due to the Italian spoils system, the development of the bureaucracy has been dictated by external pressures and contingences rather than by principles linked to the State itself. The autonomous status of the Sicily Region translates this phenomenon at the regional level, and fosters patronage dynamics that are particularly powerful in Sicily ${ }^{38}$. In this sense, the implementation of the European Cohesion Policy appears to be in line with an institutional practice and marked by a "hidden agenda" of the ruling classes trying to prevent the emergence of new players who could challenge their power $^{39}$. In other words, the partnership principle promoting an inclusive cohesion policy has been contrasted with the priority to maintain a status quo. In the end, the powerful regional government in Sicily remained by far the main beneficiary of these funds while the cultural field and the world of art, poorly organized, were left aside.

The analysis of the Sicilian case raises a series of issues related to the implementation of the cohesion policy in Europe. Over the last thirty years, regional administrations have adopted European standards and norms in their works, numerous links were established across Members States' borders and beyond through interregional programmes, and thousands of cultural operators and artists have developed a great variety of cultural works all throughout the continent that were funded under this

36 For instance LA SPINA, Antonio - La politica per il Mezzogiorno. Bologna: Il Mulino, 2003. ISBN 9788815093431 and FELICE, Emanuele - Perché il sud è rimasto indietro. Bologna: Il Mulino, 2013. ISBN 9788815266101.

37 CASSESE, Sabino - L'Italia: una società senza stato?. Bologna: Il Mulino, 2011. ISBN 9788815233783.

38 PIATTONI, Simona - Le virtù del clientelismo. Una critica non convenzionale. Bari: Laterza, 2007. ISBN 9788842083399.

39 LA SPINA, Antonio - La politica per il Mezzogiorno, ibid. 
policy $^{40}$. And yet, the divergent interpretation of sensitive concepts, the divergences in the definition of shared strategic development choices, and the obstacles impeding a broader involvement the continent funded by this policy of players in the implementation of this policy challenge the building of a cohesive European society. Indeed, the increased socio-economic disparities that can be found in Europe question the effects of this policy, which may reflect what Philippe Davezies calls a "new territorial egoism", characterized by an increasing refusal of solidarity that challenges the European casa comum within and beyond its borders ${ }^{41}$.

\section{The role of European Cultural networks and their relationships with EU institutions in transnational cultural cooperation}

As mentioned before, artists and cultural actors have not been waiting for the EU to design policies or cultural programmes to work together: there are strong cultural dynamics that have structured the European cultural scene and that continue to do so beyond the EU frameworks, with or without communitarian support. European cultural networks, gathering thousands of cultural organisations all over the continent and beyond, play today a specific role as powerful engines for transnational cooperation. The study of their role and their relation with the EU institutions, focussing on the methodologies and instruments the EU has designed to respond to their needs, will offer another perspective to explore the EU action and the mobilisation of cultural players in shaping a European casa comum ${ }^{42}$.

\subsection{The emergence of European cultural networks as essential players on the international cultural scene}

European cultural networks emerged in the 1980s and hundreds of them are active today in all artistic disciplines. Resulting from bottom-up dynamics linked to the spontaneous will of a few professionals to gather and deal with a common theme, some of them grew to reach up to 500-600 members today. Being flexible structures that continuously negotiate their positioning and evolve, they can be viewed as interest groups as described

40 KEA European Affairs - Use of structural funds for cultural projects. Study prepared for the European Parliament, 2012.

41 DAVEZIES, Philippe - Le nouvel égoïsme territorial. Le grand malaise des nations. Paris: Seuil, 2015. ISBN 9782021230154. The serious crisis linked to the management of migration in Europe is another episode challenging European solidarity today.

42 AUTISSIER, Anne-Marie - La construction d'une action publique culturelle européenne: entre mobilisations des acteurs et inachèvements institutionnels. HDR: Université Pierre Mendès France de Grenoble, Université Saint Denis, 2011. 
by Sabine Saurugger and Emiliano Grossman ${ }^{43}$. Their adaptability to evolve in the changing environment of the network societies is high, and reference can be made to Manuel Castells' work who developed a theory on networking societies ${ }^{44}$. Usually coordinated by a simple structure facilitating communication between their members and promoting their activities, networks in return depend heavily on the involvement of their members, on their financial contributions and on their commitment to the activities of the network. These activities include the organisation of meetings of different sizes and formats that involve small assemblies or large ones with up to 500 people; the publication of topical documents addressing their members' needs (business plan for the cultural sector, working with refugees, mobility issues in the performing arts sector); or trainings, artistic events and various initiatives that could benefit their members, such as the project On-the-move ${ }^{45}$ which provides information and disseminates opportunities related to cultural mobility internationally. Cultural networks also develop advocacy activities targeting their national institutions as well as European institutions. Thanks to the growing number of their members, based all over Europe and beyond, these influential players became increasingly legitimate as representatives of the cultural field in European institutional circles.

Through their transnational action, which promotes cooperation and collaboration among thousands of organizations of various kinds, these networks play an important role in the construction of Europe. They are elemental in increasing the knowledge of their members about the cultural scene at the international level, and in developing their capacities to work at a global scale - they became "cognitive" places, according to Judith Staines ${ }^{46}$, and constitute the matrix for the productions and co-productions touring in festivals that blossomed at the beginning of the $21^{\text {st }}$ century. And as they are particularly active in sustaining innovative aesthetic forms, questioning the hierarchy in the arts, they contribute to discover challenging artistic works and circulate them on national tour and promote their artistic diversity throughout the continent - the case of Circostrada, a large network promoting circus and street art across Europe, is emblematic of this phenomenon ${ }^{47}$. They also pay attention to audiences that have poor access to culture, devising new strategies, readapting industrial facilities ${ }^{48}$ or creating new projects to transform heritage sites ${ }^{49}$ to offer new opportunities in cities or rural areas deprived of

43 GROSSMAN, Emiliano, SAURUGGER, Sabine - Les groupes d'intérêt. Action collective et stratégies de representation. Paris: Armand Collin, 2006. ISBN 9782200259983.

44 CASTELLS, Manuel - The Information Age: Economy, Society and Culture. Vol. 1. The Rise of the Network Society. Hoboken: Wiley-Blackwell, 1996. ISBN 9781557866172.

45 [OnLine] [20 ${ }^{\text {th }}$ May 2018]. Available at www: https://on-the-move.org>.

46 STAINES, Judith - Working groups: network solutions for cultural cooperation in Europe. Brussels: EFAP, European Forum for Arts and Heritage, 1996.

47 [OnLine] [20 ${ }^{\text {th }}$ May 2018]. Available at www: <URL http://www.circostrada.org/en>.

48 TransEuropeHalles, gathering cultural centers initiated by citizens and artists [OnLine] [20 ${ }^{\text {th }}$ May 2018]. Available at www. http://teh.net>.

49 Association of Cultural Encounter Centres [OnLine] [20 $0^{\text {th }}$ May 2018]. Available at www: https:// www.accr-europe.org/?lang=en>. 
cultural infrastructures. Last but not least, they explore and support the cultural scene emerging at the margins of the EU, or even beyond its borders. Cultural networks were present in Eastern and Central Europe right from the eighties - that is much before the Enlargement, and they are expanding today in the Mediterranean area (IETM ${ }^{50}$, gathering players from the performing arts sector focussing on European neighbours) or globally as ENCATC ${ }^{51}$ (network for cultural management and policies). Challenging the borders of Europe and overcoming national frameworks, European cultural networks may be seen as the cosmopolitan players Beck and Grande deem necessary to deepen the European project ${ }^{52}$. Fostering mobility and transnational cooperation, developing professional capacities, and expanding their action globally, they claimed to be acknowledged as major European cultural players who could enjoy support from the EU institutions to strengthen European cultural cooperation.

\subsection{Cultural networks and EU institutions: a turbulent relationship}

In spite of European cultural networks pretensions towards the EU institutions, the recognition of the role they could play EU level has been laborious and is still fragile. Following the analysis of Anne-Marie Autissier who has explored the role of European Cultural networks in contributing to shape a European cultural action ${ }^{53}$, networks began to develop advocacy work towards the EU at the beginning of the nineties, hoping to be influential at a time when they could offer their professional expertise to the communitarian staff that was not prepared to deal with cultural matters. To do so, they founded a cultural network especially dedicated to advocate culture towards the EU institutions, Culture Action Europe network ${ }^{54}$. They also explored the different programmes where they could identify funding opportunities for their members, acting as mediators towards EU instruments, and in some cases they submitted proposals themselves, aiming at developing projects that could serve their communities. Autissier underlines that the European Commission was initially rather embarrassed towards this new category of players. As cultural networks do not gather members that are recognised as representatives at the national level, their legitimacy to speak on behalf of a professional field could be put into question. In addition, some Member States were not particularly supportive of these

50 [OnLine] [20 ${ }^{\text {th }}$ May 2018]. Available at www: https://www.ietm.org>.

51 [OnLine] [20 ${ }^{\text {th }}$ May 2018]. Available at www: https://www.encatc.org>.

52 BECK, Ulrich and GRANDE, Edgar - Cosmopolitan Europe. Cambridge: Polity Press, 2007. ISBN 9780745635637.

53 AUTISSIER, Anne-Marie - La construction d'une action publique européenne: entre mobilisations des acteurs et inachèvements institutionnels. Grenoble: Presses Universitaires, 2015.

54 Culture Action Europe has the mandate to develop advocacy work for the cultural field on behalf of networks. Previously named EFAH (European Forum for the Arts and Heritage), this network has led a campaign during the last EU budget negotiations, stemming from the cross-cutting dimension of culture, to guarantee that $1 \%$ of the amounts allocated to all policy sectors should be dedicated to culture. 
cultural networks, which were not considered as valid interlocutors, and the Commission did not want to bypass or upset them. Also, the Commission needed quick results and visible outputs that are usually produced through the development of projects, while cultural networks were asking for support to their organisation to develop their activities on the longer term. The issue of time and visibility is particularly challenging for networks as it is very difficult for them to give evidence of what they $\mathrm{do}^{55}$. In spite of the strong commitment of their members, and their on-going relations and interactions with their national and regional authorities, they suffer from a lack of understanding and poor recognition of their work, and they have to strive to secure their funding. The European Parliament was the first EU institution to hear the claims of the networks, and to dedicate a small budget to the running costs of these organisations. Then, the main EU cultural programme, entitled "Culture", finally recognised cultural networks as eligible at the beginning of 2000 , acknowledging their legitimacy to promote cultural cooperation. In parallel, cultural networks have progressively been invited to negotiation tables in European arenas to give their contribution either formally or informally ${ }^{56}$ to shape a cultural action.

In any case, the relationship between cultural networks and communitarian institutions that caters to build a fruitful cultural cooperation throughout the continent has its limits. First, the funding provided by EU cultural programmes did not cover all the networks' financial needs, and the situation deteriorated further under the current programme Creative Europe ${ }^{57}$. In addition, the results of the advocacy work developed by the networks look rather modest - a researcher underlines the difficulty for cultural networks to contribute to cultural policy design, mentioning the "missing link" between cultural networks and policy makers ${ }^{58}$. For some networks, the close relations they developed with European institutions has distanced them from their own members, influenced their course of action to fit EU priorities, and weakened their base - a phenomenon characterising the evolution of what the EU calls the civil society organisations working in Brussels that is well identified by political scientists ${ }^{59}$. In opposition to these dynamics, other networks

55 A study commissioned by the IETM in 2001 is one of the rare examples attempting to measure the effects of a European Cultural Network. Fondazione Fitzcarraldo - How networking works. IETM study on the effects of Networking - Arts Council of Finland, 2001 [OnLine] [20 $0^{\text {th }}$ May 2018]. Available at www: http://www.fitzcarraldo.it/en/research/IETM.pdf>.

56 Some debates took place in the framework of the "structured dialogue" promoted in the Agenda of 2007 where the EC would choose the issues to be discussed and provide a small grant to organise discussions.

57 The decrease of financial resources allocated to cultural networks led some historical networks that were operating from the beginning of the century to close their doors. This is the case of Banlieues d'Europe, a cultural network dedicated to activities taking place in the peripheries of the cities and with marginalised people. In addition, Creative Europe promotes the competitiveness of small and medium enterprises in the cultural and creative sector, echoing the evolution of the cultural paradigm identified in the cohesion policy.

58 ŠVOB-ĐOKIĆ, Nada - Cultural networks and cultural policies: a missing link. In CVJETICANIN Biserka (ed.) - Networks, The Evolving Aspects of Culture in the 21st Century. Zagreb: Culturelink/ Institute for International Relations, 2011. ISBN 9789536096572.

59 SANCHEZ SALGADO, Rosa - Europeanizing Civil Society. How the EU shapes Civil Society 
have decided to emancipate themselves from the heavy rules and constraints linked to the managing of EU funding, choosing to develop their own format and business plan outside the communitarian framework, while keeping an eye on the EU cultural action ${ }^{60}$. The maturation of the networks and their growing numbers, gathering various kinds of bodies, has thus coincided with the diversification of their strategies in relation to the EU. While some of them continue to depend heavily on communitarian support, others have explored alternative ways to sustain their activities.

An article written by Yudhishthir Raj Isar, an academic and cultural actor, sums up the main stakes and challenges related to European cultural networks today. To guarantee the effectiveness of the distinct added value these organisations are supposed to bring to cultural development, he suggests that they take into account and apply seven imperatives, among which realism, reflexivity and autonomy/audacity ${ }^{61}$. Though culture plays a central role, the cultural sector cannot pretend to contribute directly to solve global issues "that involve questions of power, or income, exploitation"; cultural networks need to be more aware of their practice and their links with their environment; finally, they should be careful to preserve their autonomy "at a time when cultural practice is increasingly instrumentalised". To put it simply, even though the impact of networks on promoting exchanges within and beyond Europe, fostering diversity and solidarity amongst colleagues, and committing to advocate for the cultural sector in Europe is acknowledged, their power remains limited. One of the main challenges they face is how to preserve a level of autonomy in their relations with EU institutions, which provide them with the financing that keeps their activities going. Being part of these networks is conditioned by the commitment of the members to fulfil a mission they have determined together, and the pressure wielded by funders such as the EU could compromise this commitment and get some members to leave the network, which in turn could doom this network to extinction as surely as the lack of financial resources.

\section{Conclusion}

The two case studies exploring the EU cultural action and the mobilisation of actors both in the peripheries of Europe and at the heart of its institutions have shown the variety and the challenges linked to the building of a cultural Europe today. The analysis of the

Organizations. London: 2014. ISBN 978137355416.

60 Such as the Fresh Arts Coalition Europe (FACE), willing to experiment new ideas and models in contemporary artistic work, or On the move, promoting cultural and artistic mobility in Europe. [OnLine] [20 ${ }^{\text {th }}$ May 2018]. Available at www: http://www.fresh-europe.org>.

61 RAJ ISAR, Yudhishthir - Cultural networks and cultural policy: some issues and imperatives. In CVJETICANIN, Biserka (ed) - Networks, The Evolving Aspects of Culture in the 21st Century. Zagreb: Culturelink/ Institute for International Relations, 2011. ISBN 9789536096572. p. 49-50. The five other imperatives are: articulation, amplitude, autonomy/audacity, adaptation and anticipation. 
European cohesion policy implementation in Sicily, an emblematic region at the crossroad of the migration flows that crystallises some of the main tensions Europe is facing today, gives a few hints about this policy's main issues. The opportunities it offers for cultural professionals and its effects are hindered by divergent objectives and strategic choices between Brussels and the regional territories, as well as the missed inclusion of numerous active cultural players in the policy implementation. As for the European cultural networks, the impact of their activities on transnational cooperation dynamics and the building of a European cultural action may to a certain extent depend on the relationship they manage to establish with their EU interlocutors. Though the cosmopolitan nature of cultural networks makes the EU institutions their natural referent, both entities have distinguished agendas and repertoires of action that may in certain circumstances lead to conflicts and lower the effectiveness of their endeavours.

The empirical analysis of the European Capitals of Culture programme, currently funded in the framework of the Creative Europe programme, and the theoretical reflection proposed by Monica Sassatelli exploring the way in which this communitarian scheme may contribute to Becoming European offers an interesting path to feed the debate and question the way the EU and cultural players may contribute to foster the role of culture as a vector for a common European house. The title of the programme itself, that does not include the expression "European Culture", shows that it may be vain to define and support a unique European culture a unique European culture. Indeed, what could appear as a weakness may actually be an opportunity for cultural operators and artists to create their own vision of Europe. The curators of an itinerary contemporary art exhibition organised for a European capital of Culture were describing their action this way:

"We wanted to live Europe, not to proclaim Europe, if you know what I mean. We didn't ask the artists to think of Europe, we asked them to think of a different town. (...) I don't think that Europe can be both, the frame and the content. Europe is only the frame, it is a general aim of all the European countries but its content is diversity." ${ }^{\prime 2}$ To support a European casa comun, based on its diversity and open to populations landing on its shores, it would then be key to provide an open framework that fits the views of cultural operators and artists and is compatible with their needs, beyond the communitarian agenda. This questions both the mainstreaming of culture in EU policies, which subordinates culture to achieve other EU policies objectives; and the governance of the EU cultural action, when the respective power of all the stakeholders with their extremely diverse interests and varied levels of intervention make the definition of an EU action for culture particularly challenging.

Artigo Recebido a 21 de junho de 2018 | Aceite a 28 de junho de 2018.

\section{Bibliography}

62 SASSATELLI, Monica - Becoming Europeans, Cultural identities and Cultural Policies. Palgrave: Macmillan, 2009. ISBN 9780230250437, p. 126. 
AUTISSIER, Anne-Marie - La construction d'une action publique culturelle européenne: entre mobilisations des acteurs et inachèvements institutionnels, HDR. Université Pierre Mendès France de Grenoble, Université Saint Denis, 2011.

BECK, Ulrich, GRANDE, Edgar - Cosmopolitan Europe. Cambridge: Polity, 2007. ISBN 9780745635637.

BECKER, Howard-S - Art Worlds. University of California Press, 2008. ISBN 9780520256361.

BOUQUEREL, Fanny - Culture et politique régionale de l'Union européenne. Acteurs et dynamiques d'un cadre d'intervention inopérant: la région Sicile, PhD thesis. Université Paris 8 Saint Denis, 2015.

BRAGUE, Rémi - Europe, la voie romaine. Paris: Gallimard, 1992. ISBN 2070408779.

CALLIGARO, Oriane, VLASSIS, Antonios - La politique européenne de la culture [Online], Politique européenne. L'Harmattan, 2017/2, n.56, p.8-28. DOI 10.3917/poeu.056.0008.

CASTELLS, Manuel - The Information Age: Economy, Society and Culture. Vol. 1 The Rise of the Network Society. Hoboken: Wiley-Blackwell, 1996. ISBN 9781557866172.

CASSESE, Sabino - L'Italia: una società senza stato?. Bologna: Il Mulino, 2011. ISBN 9788815233783.

CVJETICANIN, Biserka (ed.) - Networks, The Evolving Aspects of Culture in the 21st Century. Zagreb: Culturelink/ Institute for International Relations, 2011. ISBN 9789536096572.

DAVEZIES, Philippe - Le nouvel égoïsme territorial. Le grand malaise des nations. Paris: Seuil, 2015. ISBN 9782021230154.

FARGION, Valeria, MORLINO, Leonardo, PROFETI, Stefania - Europeizzazione e rap-presentanza territoriale. Il caso italiano. Bologna: Il Mulino, 2006. ISBN 9788815108791.

FELICE, Emanuele - Perché il sud è rimasto indietro. Bologna: Il Mulino, 2013. ISBN 9788815266101.

GIELEN, Pascal (ed.) - No Culture, no Europe. On the Foundation of Politics. Amsterdam: Antennae Valiz, 2015. ISBN 9789078088868.

GROSSMAN, Emiliano, SAURUGGER, Sabine - Les groupes d'intérêt. Action collective et stratégies de representation. Paris: Armand Collin, 2006. ISBN 9782200259983.

JUDT, Tony - Postwar. London: Vintage, 2010. ISBN 9780099542032.

LA SPINA, Antonio - La politica per il Mezzogiorno. Bologna: Il Mulino, 2003. ISBN 9788815093431.

MANZELLA, Gian Paolo - Una politica influente. Vicende, dinamiche e prospettive dell'intervento regionale europea. Bologna: Il Mulino, 2011. ISBN 9788815149282. 
MILIO, Simona - From Policy to Implementation in the European Union, The Challenge of a Multi-level Governance System. London-New York: Tauris Academic Studies, 2010. ISBN 9781848851238.

MORIN, Edgar - Penser l'Europe. Paris: Gallimard, 1987. ISBN 2070325849.

PEQUIGNOT, Bruno - La question des oeuvres en sociologie des arts et de la culture. Paris: L'Harmattan, 2007. ISBN 9782296029330.

PIATTONI, Simona - Le virtù del clientelismo. Una critica non convenzionale. Bari: Laterza, 2007. ISBN 9788842083399.

RAJ ISAR, Yudhishthir - Cultural networks and cultural policy: some issues and imperatives. In CVJETICANIN, Biserka (ed.) - Networks, The Evolving Aspects of Culture in the 21st Century. Zagreb: Culturelink/ Institute for International Relations, 2011. ISBN 9789536096572.

REMOTTI, Francesco - Cultura, dalla complessità all'impoverimento. $4^{\text {th }}$ edition. Roma-Bari: Laterza, 2011. ISBN 9788842095873.

SANCHEZ SALGADO, Rosa - Europeanizing Civil Society. How the EU shapes Civil Society Organizations. London: Palgrave Macmillan, 2014. ISBN 9781137355416.

SASSATELLI, Monica - Has Europe lost the Plot? In CHENAL Odile, SNELDERS Bas - Remappings. The Making of European Narratives. Amsterdam: European Cultural Foundation, 2012. ISBN 9789062820580.

SASSATELLI, Monica - Becoming Europeans, Cultural identities and Cultural Policies. London: Palgrave Macmillan, 2009. ISBN 9780230250437.

STAINES, Judith - Working groups: network solutions for cultural cooperation in Europe. Brussels: EFAP, European Forum for Arts and Heritage, 1996.

STEINER, George - Dans le château de Barbe Bleue, notes pour une redéfinition de la culture. Paris: Gallimard, 1986. ISBN 9782070323678.

ŠVOB-ĐOKIĆ, Nada - Cultural networks and cultural policies: a missing link. In CVJETICANIN Biserka (ed.) - Networks, The Evolving Aspects of Culture in the 21st Century. Zagreb: Culturelink/ Institute for International Relations, 2011. ISBN 9789536096-572.

VALERY, Paul - L'Européen. First published in La Revue Universelle, 1924, reprinted In Europes de l'Antiquité au XXe siècle. Paris: Robert Laffont, 2000. ISBN 9782221085752. Fondazione Fitzcarraldo - How networking works. IETM study on the effects of Networking. Finland: Arts Council of Finland, 2001.

KEA European Affairs - The Economy of Culture in Europe. Study prepared for the European Commission. Brussels, 2006.

KEA European Affairs - Use of structural funds for cultural projects. Study prepared for the European Parliament, 2012. Communication from the Commission The Single Act: A new frontier for Europe (COM (87) 100). 
Communication from the Commission The Single Act: A new frontier for Europe (COM(87)100).

Communication from the Commission. Cohesion Policy and Culture: a contribution to employment COM (96) 512 final.

Communication from the Commission concerning the Structural Funds and their coordination with the Cohesion Fund: Guidelines for the programmes in the period 2000-2006 COM (1999) 344 final.

Council Decision on Comunity strategic guidelines on cohesion (2006/702/EC).

Communication from the Commission on a European Agenda for culture in a globalizing world COM (2007) 242 final.

Communication from the Commission. Europe 2020, A Strategy for a smart, sustainable and inclusive growth COM (2010) 2020 final.

Communication from the Commission. A New European Agenda for Culture COM (2018) 267 final.

Regulation (EU) of the Parliament and the Council laying down common provisions on the European Regional Development Fund, the European Social Fund, the Cohesion Fund, the European Agricultural Fund for Rural Development and the European Maritime and Fisheries Fund $n^{\circ} 1303 / 2013$. 
